Illinois State University

ISU ReD: Research and eData

Theses and Dissertations

3-26-2019

\title{
Everything We Touch is Touching Us
}

Molly Markow

Illinois State University, memarkow@gmail.com

Follow this and additional works at: https://ir.library.illinoisstate.edu/etd

Part of the Theory and Criticism Commons

\section{Recommended Citation}

Markow, Molly, "Everything We Touch is Touching Us" (2019). Theses and Dissertations. 1077.

https://ir.library.illinoisstate.edu/etd/1077

This Thesis is brought to you for free and open access by ISU ReD: Research and eData. It has been accepted for inclusion in Theses and Dissertations by an authorized administrator of ISU ReD: Research and eData. For more information, please contact ISUReD@ilstu.edu. 


\section{EVERYTHING WE TOUCH IS TOUCHING US}

\section{MOLLY MARKOW}

\section{Pages}

Images shape both personal and collective experiences of place in the Anthropocene. I am interested in the relationship of landscape and representation to purity politics, longing, and escape. I am critical of the role of idealized depictions of "nature" and question how images shape our notions of paradise, desire, and fantasy. Who benefits from notions of paradise, and who doesn't? I ask these questions while searching for a way to embrace impurity and the beauty in contamination. How might we come to an understanding of the post-pure that leaves room for joy? Many things are entangled and true at once, and everything we touch is touching us.

KEYWORDS: representation, landscape, photography, purity politics, sculpture, anthropocene, entanglements, kitsch, escape 


\title{
EVERYTHING WE TOUCH IS TOUCHING US
}

\author{
MOLLY MARKOW
}

A Thesis Supportive Statement Submitted in Partial

Fulfillment of the Requirements

for the Degree of

MASTER OF FINE ARTS

School of Art

ILLINOIS STATE UNIVERSITY

2019 
(C) 2019 Molly Markow 


\title{
EVERYTHING WE TOUCH IS TOUCHING US
}

\author{
MOLLY MARKOW
}

COMMITTEE MEMBERS:

Sarah Smelser, Chair

Melissa Oresky

Nathania Rubin 


\section{ACKNOWLEDGMENTS}

I would first like to thank my committee. Whom without, this thesis would not have been possible. In particular, I would like to thank Sarah Smelser for her unwavering support and friendship through what has been a rewarding, tumultuous, and vibrant three years. Thank you to Melissa Oresky, Nathania Rubin, and Andreas Fischer for their continued generous intellect and belief in my work. Thank you also to Mark Ritchie who saw a spark and pushed me to attend graduate school many moons ago- without you I surely would not be where I am now. Thank

you to Anthony Hamilton; my love. My best behind the scenes collaborator, biggest support, critic, and confidant. And to my parents for the encouragement, and endless belief in my creative pursuits.

M.M. 


\section{CONTENTS}

Page

ACKNOWLEDGMENTS

$\begin{array}{ll}\text { FIGURES } & \text { iii }\end{array}$

CHAPTER I: THE BLUE OF DISTANCE

CHAPTER II: IN DEFENSE OF BEADED LIZARD KEYCHAINS 6

CHAPTER III: \#CLOUDS_OF_OUR_WORLD_ 8

CHAPTER IV: THE MYSTERY OF FLASHING FLOWERS 12

CHAPTER V: HOPE IN AN IMPURE WORLD 17

REFERENCES 


\section{FIGURES}

Figure

1. Long's Peak as seen from Longmont, CO (the Front Range) 2

2. Molly Markow, Paradise, shower curtain painting 5

3. Penelope Umbrico, Suns from Flickr (Partial) 4/28/09, photograph 8

4. Molly Markow, \#abovetheclouds \#infinity \#clouds_of_our_world \#suns-spotters \#sky \#air \#cloudporn \#skylovers \#skywatcher \#nature \#cloudlife \#beautiful \#skyview \#visionclouds \#cloudgazing \#instacloud \#smkescreensky, wood, faux fur, custom printed chiffon, drafting film, paint, bulletin board covering paper

5. Molly Markow, digital photograph

6. Molly Markow, Garden Party, custom printed satin, concrete, cinderblock, sticks and leaves

7. Groundcover, 2019, collage on panel

8. Doubletake, archival pigment print

9. Kindred Subjects, faux flower, custom printed chiffon on panel 


\section{CHAPTER I: THE BLUE OF DISTANCE}

The Anthropocene refers to a geologic epoch in which humans have become the major force determining the continued livability of the earth. ${ }^{2}$ Conditions and processes that have taken millions of years to put into place are being undone in the blink of an eye. There is no place left on earth free of human impact, making the idea of untouched wilderness a fiction we tell ourselves in order to find hope. Or perhaps more often, to escape the reality that we are all, already implicated in an impure world.

Beginning approximately 300 million years ago sediment covered granite began to uplift, giving rise to the Ancestral Rocky Mountains, and eventually to the Front Range. Running northsouth between Casper, Wyoming and Pueblo, Colorado, the Front Range rises nearly 10,000 feet above the Great Plains. Denver, CO sits on land that originally belonged to the Arapaho tribe as laid out in the 1851 Treaty of Fort Laramie. Soon after, gold was discovered and white settlers arrived in droves, leading to the Treaty of Fort Wise in 1861 and the cessation of land by tribal leaders. In 1864, the Sand Creek Massacre resulted in the deaths of hundreds of Arapaho and Cheyenne people, and soon after they were relocated out of Colorado. ${ }^{3}$

\footnotetext{
${ }^{2}$ Anna Tsing, Heather Anne Swanson, Elaine Gan, and Nils Bubandt, Arts of Living on a Damaged Planet: Ghosts and Monsters of the Anthropocene, (Minnesota, University of Minnesota Press, 2017), G1.

${ }^{3}$ Daniel Tyler, "Front Range." Colorado Encyclopedia. https://coloradoencyclopedia.org/article/front-range, (March 25, 2019).
} 


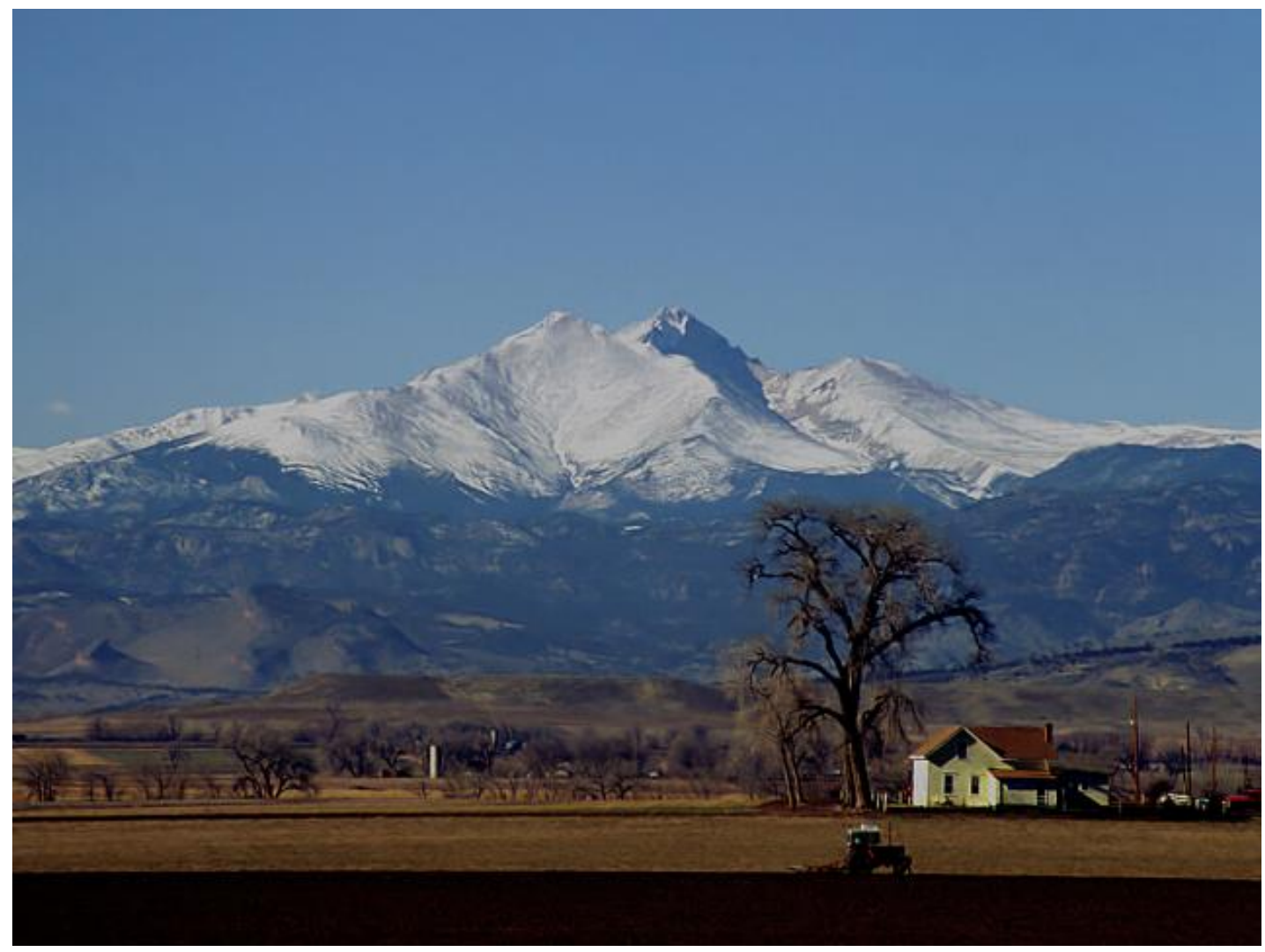

Fig. 1. Longs Peak as seen from Longmont, CO (the Front Range)

The Front Range (Fig. 1) also refers to the urban corridor that runs just east of the mountain range. Dense subdivisions, urban sprawl, fracking sites, and strip malls dot the quickly changing landscape at the foot of the mountains. On a clear day, Longs Peak looms tall, but more often, the mountains provide a constant backdrop of the blue of distance - as Rebecca Solnit describes, "the color of horizons, of solitude and desire, and the color of where you can never go." 4

Complex entanglements of development and desire exist alongside embedded histories of

\footnotetext{
${ }^{4}$ Rebecca Solnit, Field Guide to Getting Lost, (Penguin Books, 2006).
} 
militarization and colonization along the Front Range and in many places in the Western United States. These entanglements build a complex understanding of place as a crossroads, or an intersection of forces, rather than a discrete idea. My practice is comprised of movement between research, documentation, and direct material play and experimentation in the studio; akin to entagled ideas and experiences of place. I am invested in modes of making that hold space for multiplicity. By stretching and pulling at rigid binaries, I hope to re-imagine ways of being in and of the world that are more honest, speculative, and open.

Suburban sprawl along the Front Range, and the looming presence and distant desire of the granite peaks comprise my most formative and earliest memories of place. I grew up in a subdivision at the foot of the Rocky Mountains where the idea of wilderness, and "nature" loomed close, but often just out of reach. The mountains were always a place to go on weekends, or on days off from summer waitressing gigs, creating a tension between insider and outsider.

I think about the ways I feel both at home and like an intruder in sublime places. I selfishly appreciate their beauty, but am acutely aware that I unnecessarily drove my car to get there. I remind myself that many things can be true at once. I think about the sense of longing faraway places prompt, and why this is. I think about how a photo, screensaver, postcard, shower curtain, or calendar, are supposed to be the next best thing if you cannot go to these places.

Tourism serves as a potent example of the ways that neoliberal representations of place, and its subsequent experience, are inseparable and intimately entangled. Growing up along the Front Range, I grew to know and love the mountains that loomed tall along the horizon. On trips to the mountains I never felt fully like a tourist, or a genuine mountain dweller. Rather, I found myself somewhere in between, observing the two opposing forces as they interacted with one another and the land itself. 
Notions of paradise, desire, and escape have been central tenets to my thesis work and research. Who has the ability to escape and who doesn't? What role do images play in relation to these topics, and how do they shape our ideas of place both near and far? It is often a privileged activity that creates a form of othering between tourist and local. Entire communities subsist on tourism economies often as a result of complex histories of colonization and militarization. In Tourism and the Semiotics of Nostalgia John Frow unpacks the ways that tourism relates to power structures and the notion of the center and the periphery. Ultimately he concludes that tourism is built on commodification in a material sense, and also the immaterial commodification of a relation to the cultural Other. ${ }^{5}$

Paradise (Fig. 6) pokes at the complexities of tourism and notions of escape through its materiality and the conceal/ reveal function of the pink paint as it obscures and reveals the ubiquitous tropical landscape underneath. A cheap, mass produced object, the shower curtain relates both to the commodification of the idea of a pure place, and also the notion of purity as a mode of cleanliness, to wash ourselves clean of responsibility. Paradise is tied at the bottom with paracord, or camping rope. The intentional inclusion of a material commonly used in exterior spaces, with the interiority of a shower curtain allows the piece to bristle and bump up against expectations of public and private, intimate, and universal.

${ }^{5}$ John Frow, “Tourism and the Semiotics of Nostalgia." University of Melbourne (1991): 123151. http://hdl.handle.net/11343/34273 


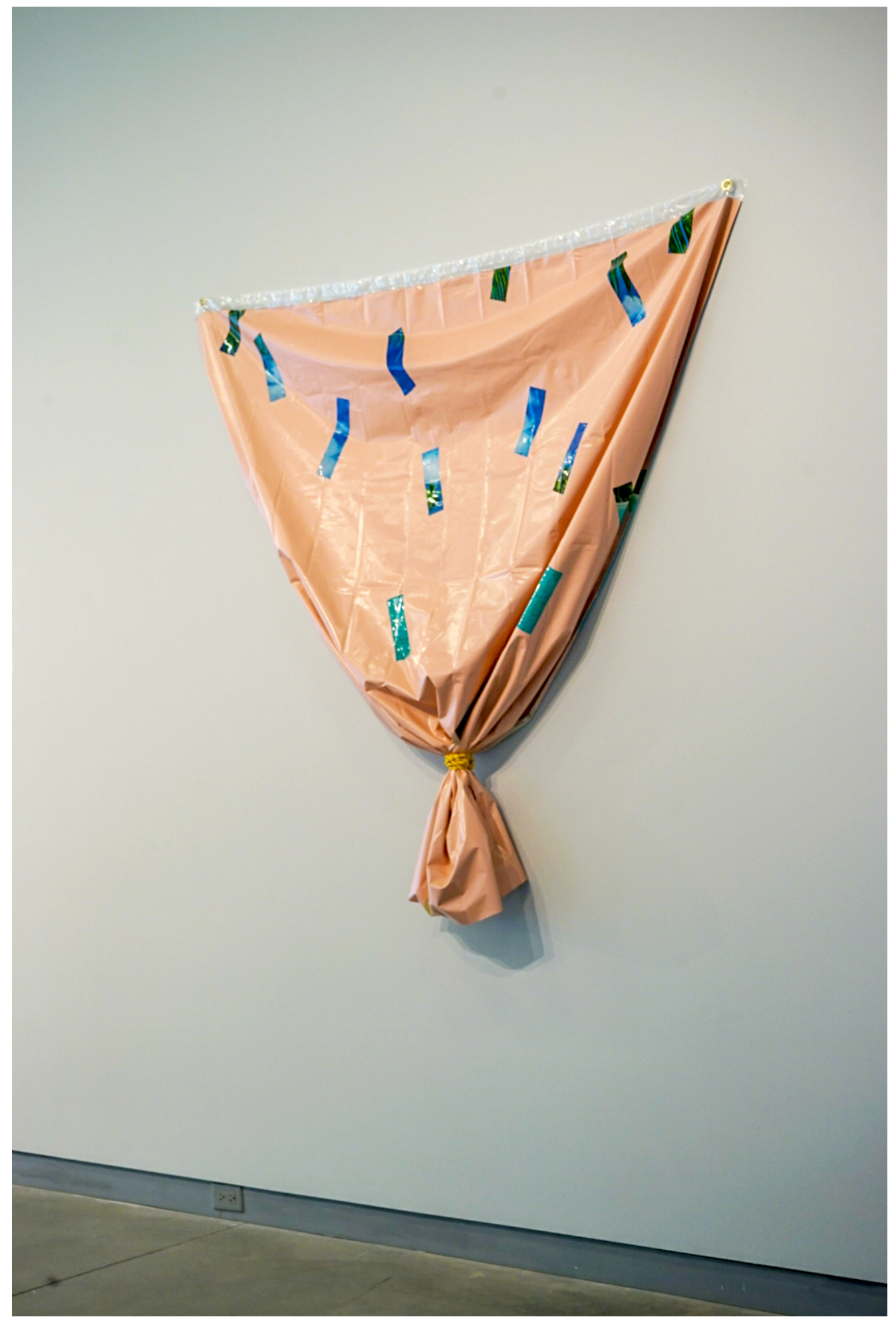

Fig. 2 Molly Markow, Paradise, shower curtain painting 


\section{CHAPTER II: IN DEFENSE OF BEADED LIZARD KEYCHAINS}

I remember the stories from friends who were Boy Scouts who got to go deep into the backcountry for weeks at a time, learning wilderness first aid and survival skills. While in Girl Scouts, we learned how to make beaded lizard key chains and went on field trips to the zoo.

In my work and research I am interested in the beaded lizard key chains, cell phone snapshots, and stock imagery, or what Hito Steyerl deems "poor images". 6 In the essay "In Defense of the Poor Image" Steyerl defines a poor image as a copy in motion, one with poor quality and resolution. A poor image is removed from the real thing, and instead is about its own conditions of fractured and flexible existence. I am curious about the ways a \$7.99 tropical landscape shower curtain, or the ubiquitous screensaver of El Capitan in the Yosemite Valley, reveal as much about our relationships to objects, materials, and place as breathing in the air of a Rocky Mountain vista.

This process of flattening hierarchical systems of taste and value is implicated in the history of craft and kitsch. Kitsch has historically been used to differentiate between high and low as a mode of reinforcing hierarchies, particularly within the history of Modernism. Clement Greenberg reinforced these binaries in his 1939 essay, “Avant-Garde and Kitsch.” Greenberg defines kitsch as a simulacra of real culture, resulting from the industrial revolution, and positions it as the rear-garde in opposition to the avant garde. He includes things such as, "popular, commercial art and literature with their chromeotypes, magazine covers, illustrations, ads, slick and pulp fiction, comics, Tin Pan Alley music, tap dancing, Hollywood movies, etc.,

\footnotetext{
${ }^{6}$ Hito Steyerl, “In Defense of the Poor Image.” E-flux Journal \#10-November 2009. https://www.e-flux.com/journal/10/61362/in-defense-of-the-poor-image/, (April 16, 2019)
} 
etc." 7 Greenberg's notion of kitsch relies on a set of binaries that create a hierarchy between high and low, good taste and bad, real culture, and its simulacra.

My studio practice incorporates mass produced shower curtains, found posters, and lowgrade materials alongside custom printed fabrics, constructed panels, and archival digital prints. I use these tactics to argue against kitsch and to question dominant systems of value and representation. Encountering a tropical landscape on a shower curtain, or a low quality poster of a tropical landscape that says "RELAX," are effectively just as real and perhaps more accessible, than the sublime experiences of place which we elevate (i.e. a mountain vista in a national park).

\footnotetext{
${ }^{7}$ Clement Greeberg, “Avant-Garde and Kitsch,” 9.
} 


\section{CHAPTER III: \#CLOUDS_OF_OUR_WORLD_}

Floods of images both mass-produced and personal; of the sky, sun, moon, stars, tropics, mountains, and sunsets, have simultaneously heightened and diminished our sense of wonder in a new infinite that we've created: an infinite defined by the limitlessness of data and information, and the quickly disappearing beauty of the landscape. Penelope Umbrico explores the circular nature of this phenomenon in her project Suns from Sunsets from Flickr, (Fig. 2) where she isolates and explores the presence of amateur photographs of sunsets on Flickr. This project is a compelling investigation of a great natural force and source of life, made multiple in the electronic space of the Internet and cool light of a screen.

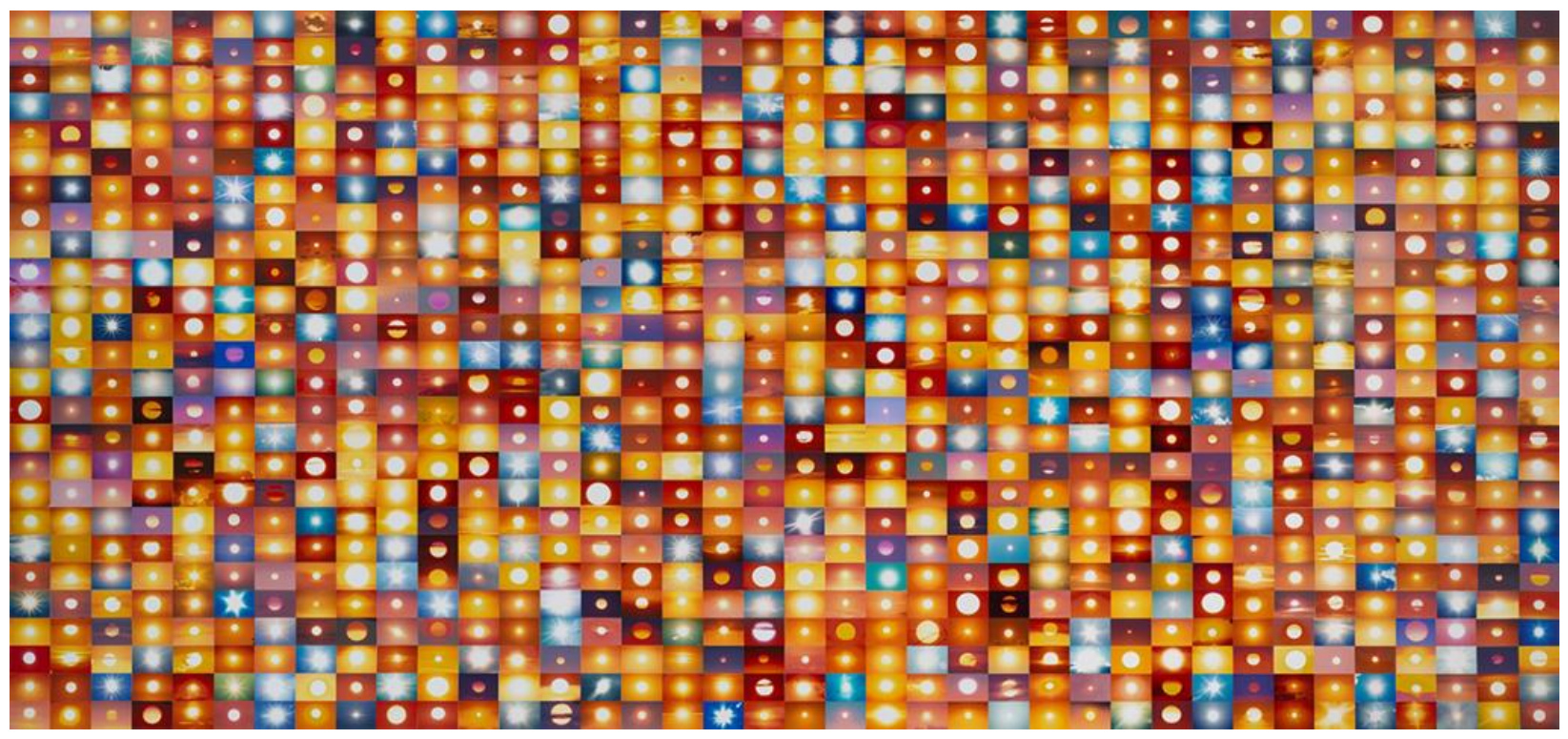

Fig. 3. Penelope Umbrico, Suns from Flickr (Partial) 4/28/09, photograph.

I am interested in the ways we create meaning and connection to place through a collision of the virtual search and lived experience. Both in terms of the Google search, but also the search 
for meaning and belonging, the shared sentiment of trying to understand the far reaches of the cosmic, alongside the banal, ordinary moments of everyday life. The daily practice of checking the Mystic Monday tarot app on my phone and viewing a starry sky at 10,000 feet are not that far apart, illuminating the multitude of ways we search for wonder. A cheap 50-foot roll of pixelated cloud paper from Amazon, is connected in my mind to the experience of photographing the landscape from an airplane window at 35,000 feet. Both are images mediated by a vast distance, complex technology, speed, and a series of screens. The speed of a plane, with an airplane window, and a cell phone camera met by the speed of Amazon delivery, the screen of a computer, and a roll of blue, sky paper made to cover bulletin boards, functioning as a screen for a windowless classroom. It is a vast territory to traverse in 60 seconds, but it is all really elastic in my mind, in the way ideas and experiences live and function, and are affected by technology and a deeper, more cosmic connection to the world. 


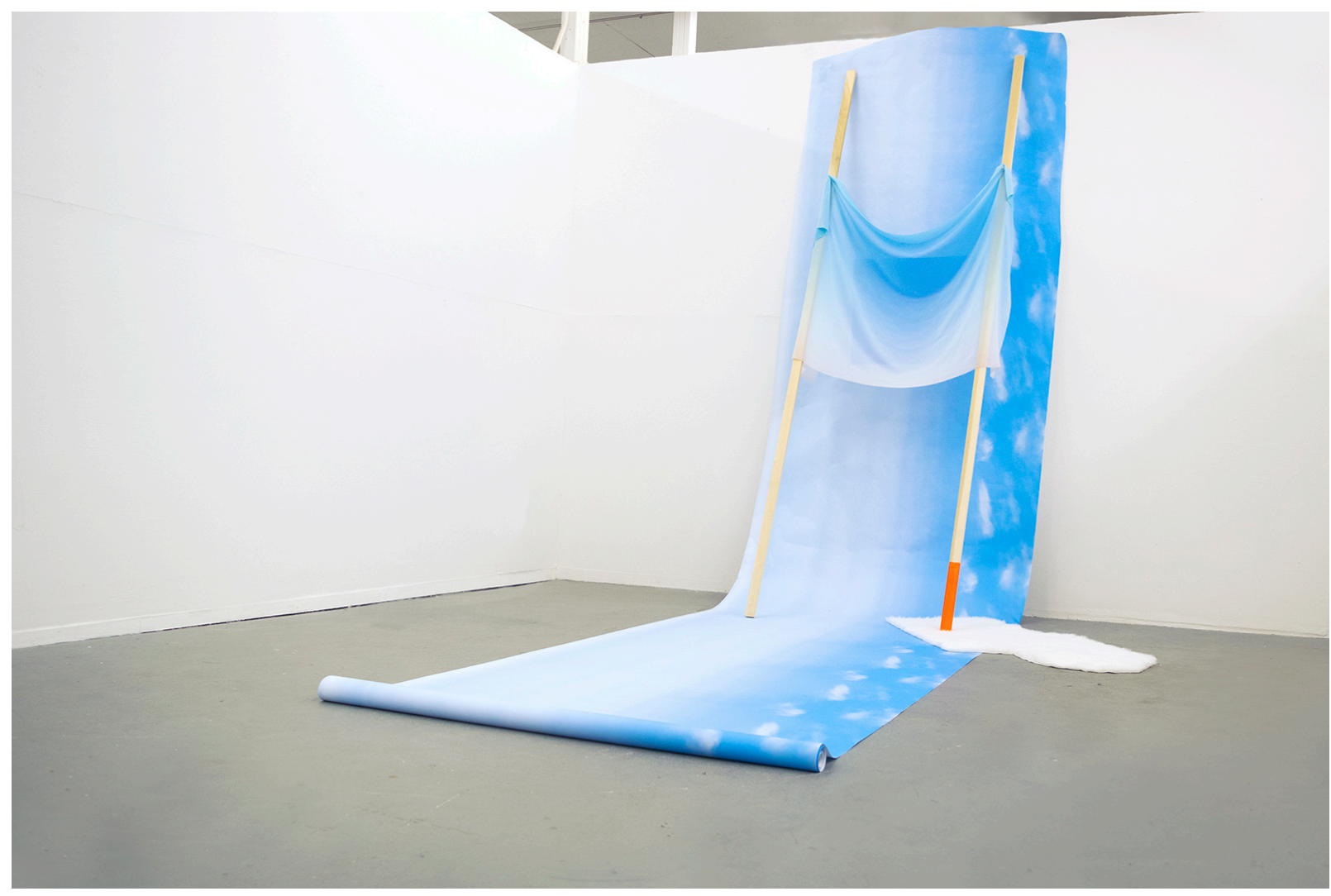

Fig. 4. Molly Markow, \#abovetheclouds \#infinity \#clouds_of_our_world \#suns-spotters \#sky \#air \#cloudporn \#skylovers \#skywatcher \#nature \#cloudlife \#beautiful \#skyview \#visionclouds \#cloudgazing \#instacloud \#smkescreensky, wood, faux fur, custom printed chiffon, drafting film, paint, bulletin board covering paper

\#abovetheclouds \#infinity \#clouds_of_our_world \#suns-spotters \#sky \#air \#cloudporn \#skylovers \#skywatcher \#nature \#cloudlife \#beautiful \#skyview \#visionclouds \#cloudgazing \#instacloud \#smokescreensky (Fig. 4) is comprised of a 50-foot roll of pixelated repeating cloudy sky, digitally printed on butcher paper from Amazon, paired with wood, faux-fur, a cell-phone snapshot of a gradient of the sky printed on chiffon, neon orange paint, and transparent blue drafting film. The materials are meticulously arranged to feel as if they are playfully combined by chance, or happenstance. Faux-fur humorously mimics the wispy clouds it rests on, while the 
neon orange foot of the wood radiates a cautionary glow. The chiffon and transparent blue drafting film reinforce the blue of the paper, the blue of the sky, the blue of distance, and the cool blue light of a screen.

The installation explores the role of cloud imagery on social media, a widely held desire to capture the shared experience of looking up, and the liminal space of the sky. The piece uses low-grade materials to create an immersive experience, akin to the actual experience of cloud gazing under a wide-open sky. The sky is at once specific to a particular place and time of day, pollution levels, and universal in its status as sign and representation. At the time of writing this, there are 195 million posts on Instagram with the hashtag sky (\#sky). Many of the posts depict sublime sunsets, glowing clouds, and photos of the moon. Sunset and cloud photos in particular, are some of the most ubiquitous and culturally devalued images. In one instance, photography has turned natural phenomena to kitsch, while in another, the ubiquity of photographs of sunsets and the sky represent something significant (hope, beauty, memory, celebration) that endures. ${ }^{8}$ This phenomenon has simultaneously done both of these things. It is kitsch and profound. This is the nature of cliché- the most heartfelt is often the most obvious, both personal and impersonal.

\footnotetext{
${ }^{8}$ Ben Burbridge and Annebella Pollen, Photography Reframed. (I.B. Tauris, 2018), 74-81.
} 


\section{CHAPTER IV: THE MYSTERY OF FLASHING FLOWERS}

A backpacking trip always starts with a parking spot at the trailhead. I often think back on the experience of pulling over on Highway 287 at midnight on the Colorado-Wyoming border to look at the great expanse of the Milky Way, or watching the light change through my windshield on Tioga Pass in Yosemite National Park. In these moments I felt a slowing down, and a remarkable sense of wonder at cosmic time and geologic process, despite the fact that I was still taking sharp curves in my car at $50 \mathrm{mph}$. These experiences reinforce the notion that we are natural when we are looking at natural things, however unnatural our conditions at the time may be.

I have vivid memories of hiking in the backcountry and seeing various blaze orange signs, markers, and spray painted markings on trees. More recently, since moving to Central Illinois, I have accumulated a multitude of photographs of blaze orange traffic cones and spray painted markings on the pavement. Blaze orange is often the color of the artificial, of danger, and of fear. Pops of blaze orange and similarly saturated colors appear throughout this body of work as a stark refrain of the hyper saturated and the artificial.

Garden Party (Fig. 6) began with a cell phone snapshot (Fig. 5) taken on a warm day, as the brightly saturated indecipherable language of construction markings on the sidewalk echoed the intense orange of Zinnia flowers in full bloom. The flowers were growing in the middle of a public sidewalk in a flowerbed, rather than in a front yard or a private garden. Similar to the function of blaze orange as a vibrant cautionary glow, the bright orange of flowers in the Tropaeolaceae family (zinnia, calendula, nasturtium) create an illusory flashing sensation in low 
light, often referred to as the "mystery of flashing flowers" or the Elizabeth Linneaus phenomenon. ${ }^{9}$

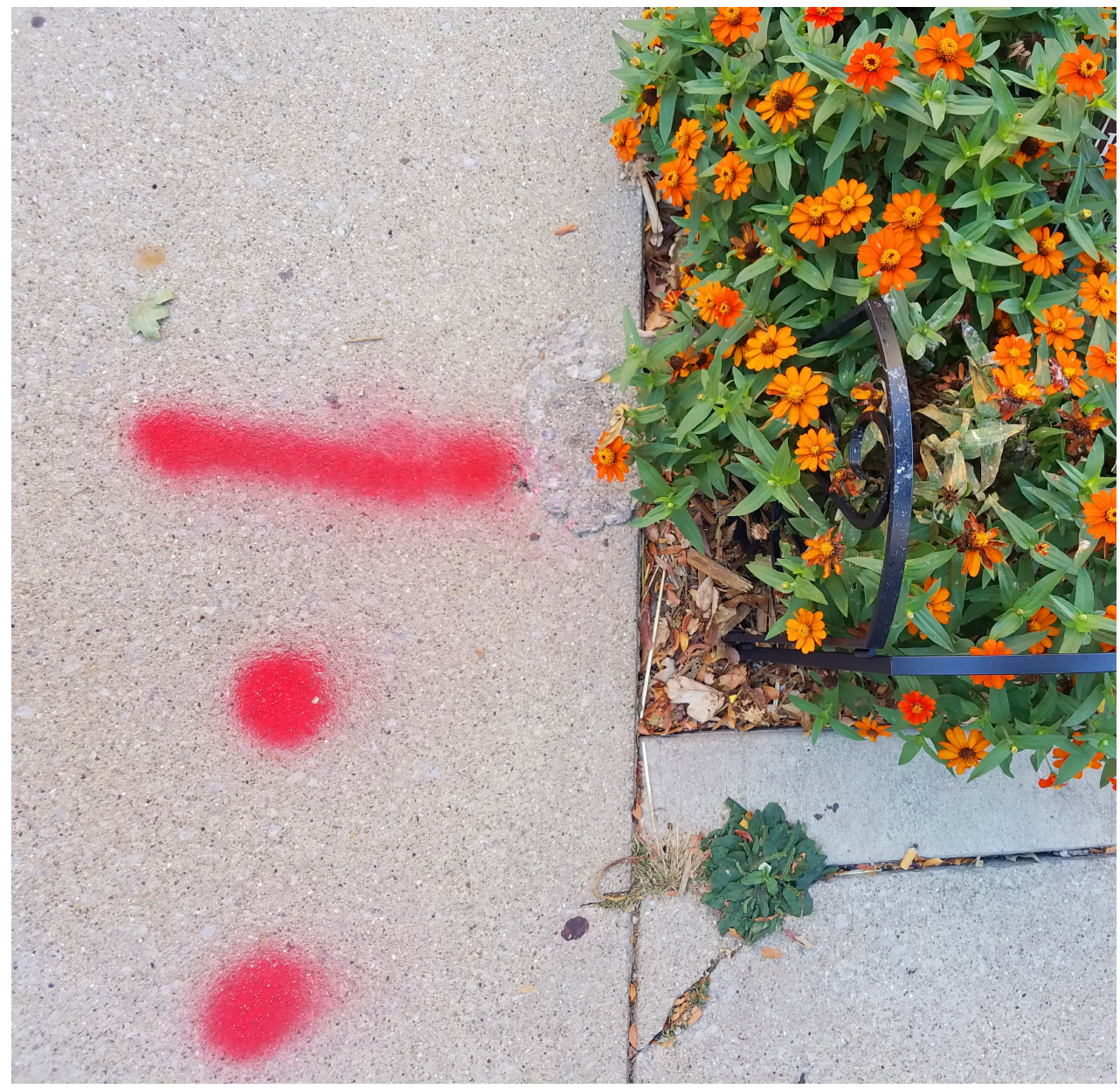

Fig. 5. Molly Markow, digital photograph

\footnotetext{
${ }^{9}$ Fred Blick, "Wordsworth, Coleridge, Science and Flashing Flowers: The Influence of Elizabeth Linnaeus and Erasmus Darwin." https://www.academia.edu/12902335/Wordsworth_Coleridge_Science_and_Flashing_Flo wers_The_Influence_of_Elizabeth_Linnaeus_and_Erasmus_Darwin, (March 25, 2019).
} 
Urban areas are more natural and accessible than the idea of untouched wilderness or the space of a National Park. Green spaces, gardens, flowerbeds and parks are intertwined in their own politics of privilege and access. However, many are accessible on foot, and dot backyards, neighborhoods, and rooftops in urban areas.

The garden, and subsequently the act of gardening, carries great metaphorical force. The garden as metaphor might refer to the Garden of Eden as a site of purity and lost innocence, while the act of gardening may reference the act of caring for land, and building hope out of despair.

Garden Party is animate and playful, familiar yet ambiguous. Though small in scale, it asserts itself through its physical weight and solid presence. The piece consists of a cell phone photo printed on satin, sewn together, and filled with concrete. It rests on a weathered cinder block with leaves, sticks and debris stuck inside. Embracing slippage, it humorously collapses both public and private space, photographic representation and the physical object itself. I am curious about the ways public and private space become defined and separated, and the differing levels of attention and care that both receive. Through this sculpture I am asking, do we have to own something to care deeply for it? I am curious about the differing levels of care public and private spaces receive. How does a sense of ownership influence the amount of care and attention we give to a place? How might we push past notions of individual ownership to forms of collective care that extend beyond the confines of a garden or a fence? 


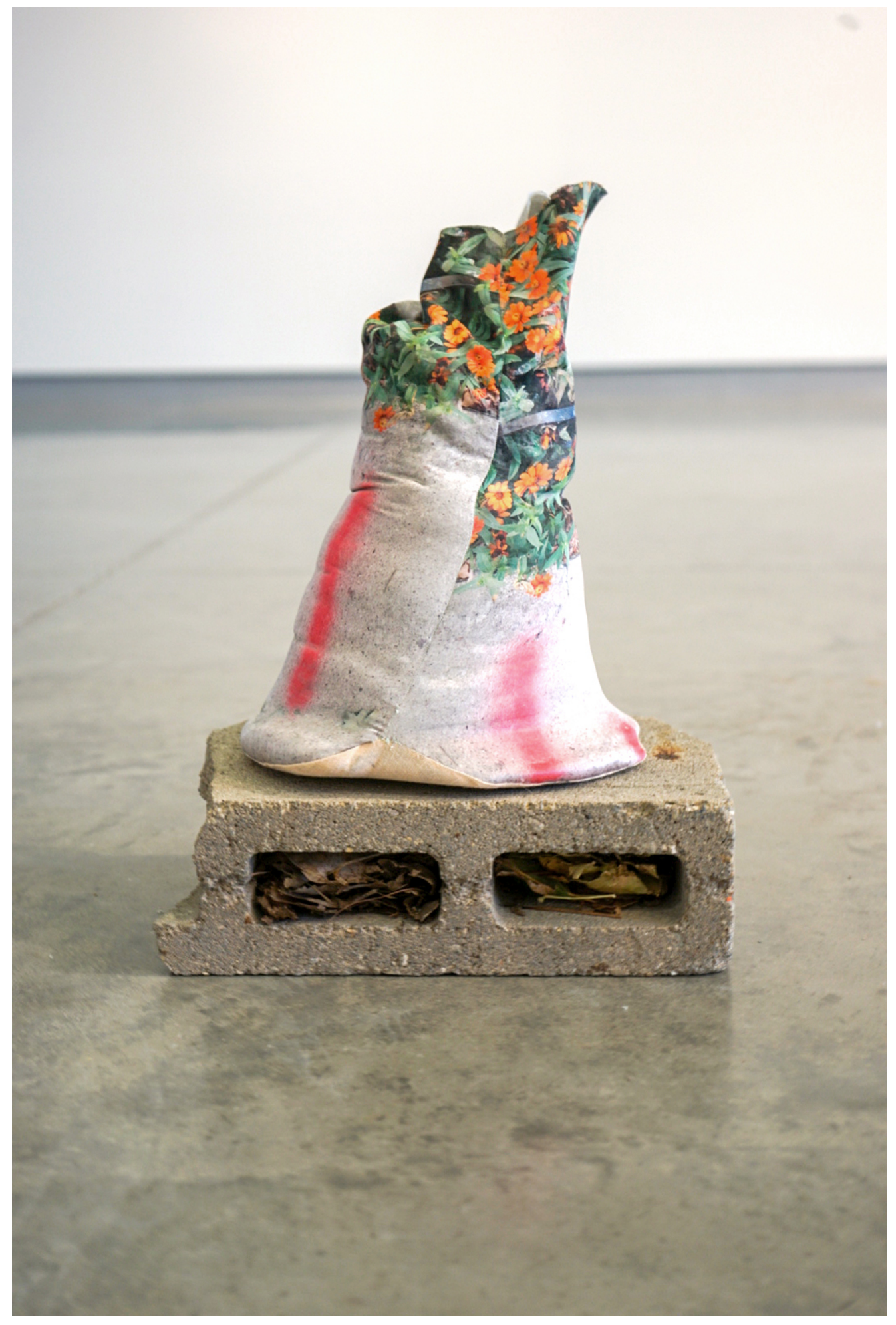

Fig. 6. Molly Markow, Garden Party, custom printed satin, concrete, cinderblock, sticks and leaves 
Garden Party is animate and playful, familiar yet ambiguous. Though small in scale, it asserts itself through its physical weight and solid presence. The piece consists of a cell phone photo printed on satin, sewn together, and filled with concrete. It rests on a weathered cinder block with leaves, sticks and debris stuck inside. Embracing slippage, it humorously collapses both public and private space, photographic representation and the physical object itself. I am curious about the ways public and private space become defined and separated, and the differing levels of attention and care that both receive. Through this sculpture I am asking, do we have to own something to care deeply for it? I am curious about the differing levels of care public and private spaces receive. How does a sense of ownership influence the amount of care and attention we give to a place? How might we push past notions of individual ownership to forms of collective care that extend beyond the confines of a garden or a fence? 


\section{CHAPTER V: HOPE IN AN IMPURE WORLD}

While remaining critical of notions of purity and escape, I am committed to maintaining hope in the midst of an entangled mess. Hope is not a belief that everything was, or will be, fine. Rather, it is about complexity and uncertainty, making space for multifaceted questions and nuanced answers. Hope can manifest in a multitude of ways. In the studio, it takes the form of play, and discovery. "Hope locates itself in the premises that we don't know what will happen and in the spaciousness of uncertainty is room to act," Rebecca Solnit remarked in her work titled Hope in the Dark. ${ }^{10}$

I want my work to incorporate intense criticality and seriousness alongside humor, play, and joy. The title of my thesis exhibition Has the Sky Fallen? is simultaneously foreboding, humorous, and absurd, while framing my works alongside a larger practice of questioning, play, and critical analysis. The works I included in Has the Sky Fallen? reflect various image-making practices existing at different levels within a larger hierarchy of value and representation. $35 \mathrm{~mm}$ photographs printed on chiffon exist alongside a digital c-print, a found poster, and a photograph printed on satin, mounted and collaged onto panel. My decision-making process and the evidence of my hand are present to varying degrees across the works. It was important for me to include works that could inform one another as a viewer moves around the space.

\footnotetext{
${ }^{10}$ Rebecca Solnit, Hope in the Dark: Untold Histories, Wild Possibilities. (Chicago: Haymarket Books, 2016), 10.
} 


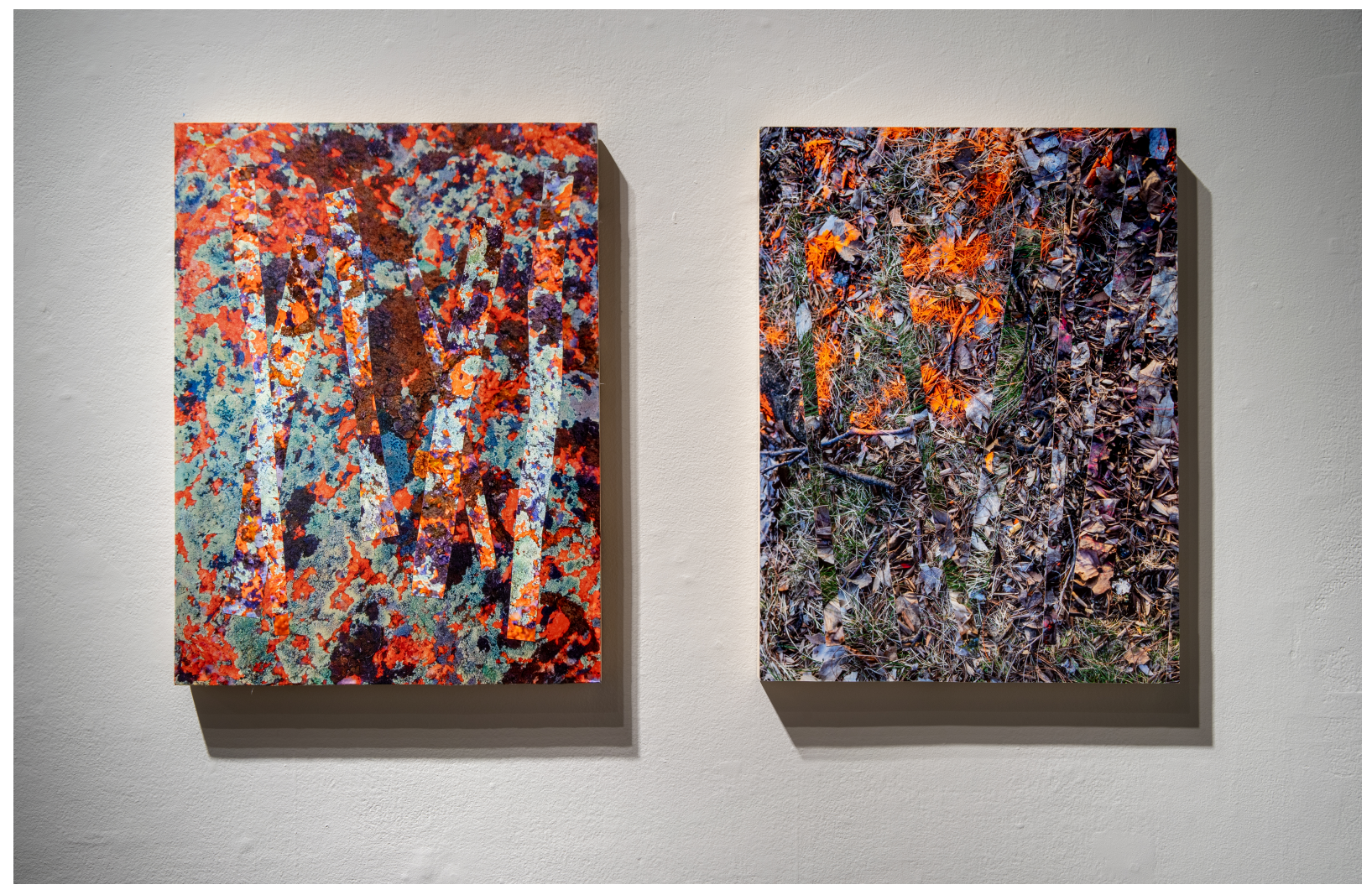

Fig. 7. Groundcover, 2019, collage on panel

The spray painted orange markings on the right panel of Groundcover (Fig. 7) echo the red spray paint markings on Garden Party (Fig. 5), while the highly saturated image of lichen in the left panel of Groundcover echoes the subdued image of lichen in the panel image of Kindred Subjects. (Fig. 9) An over-sized pink faux flower in Kindred Subjects points to the large fake plant gathering dust in the shop window of Doubletake. (Fig. 8) It is my hope that as a viewer moves around the space they become aware of their own process of looking, while encountering fast and slow speeds of viewing accentuated by notes of fragility, hope, humor, and dystopia. 


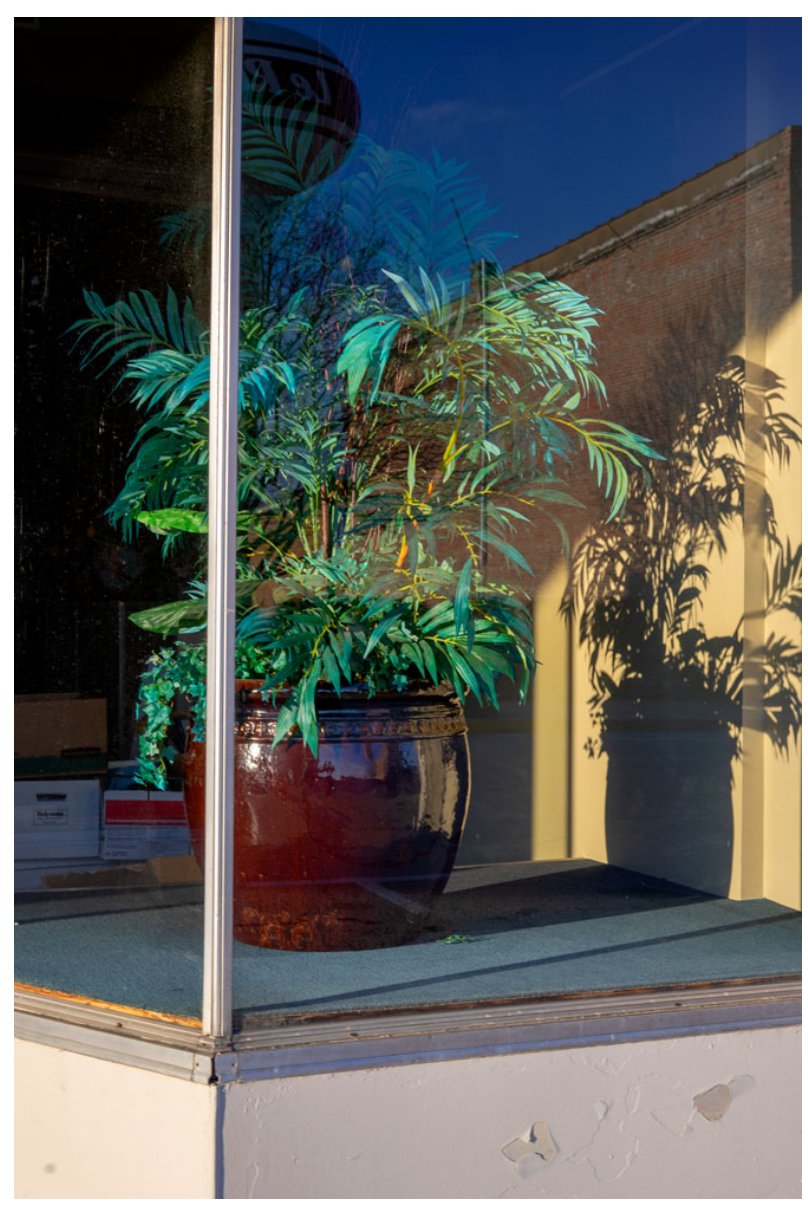

Fig. 8. Doubletake, archival pigment print

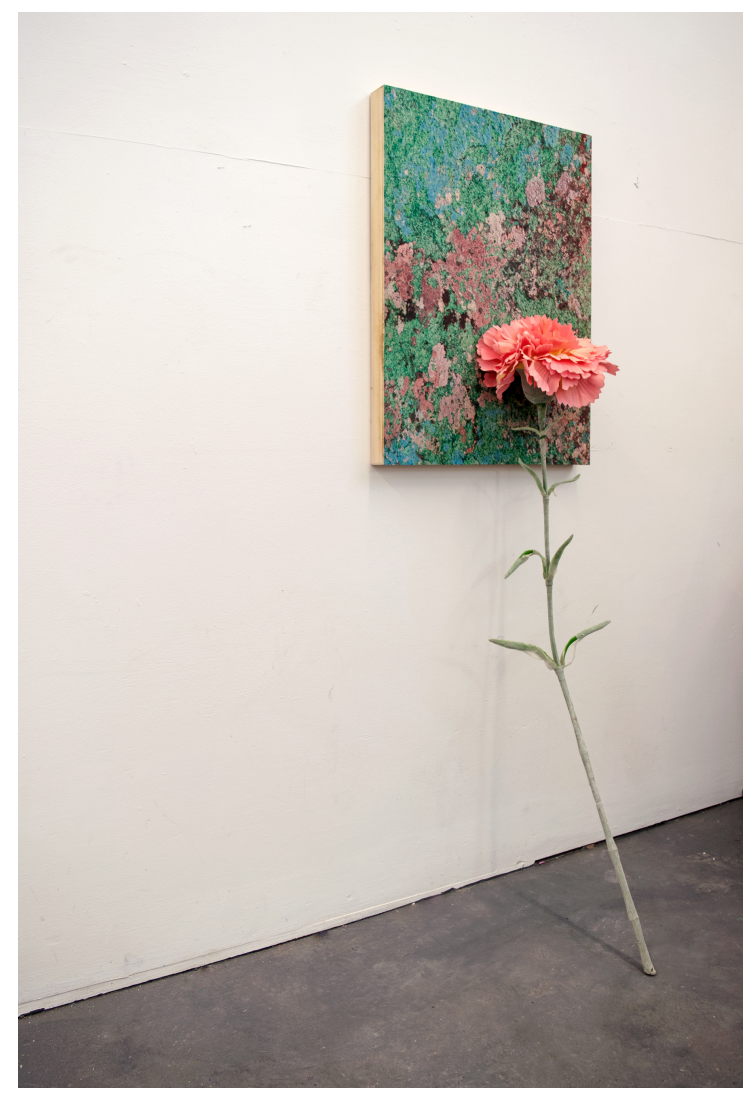

Fig. 9. Kindred Subjects, faux flower, custom printed chiffon on panel

Alexis Shotwell takes a similar position in the closing chapter of Against Purity. Shotwell argues for an awareness of our own implication in a compromised and impure world, and the injustices that inform our daily lives. She argues for a collective orientation towards flourishing, ways of being we cannot predict, and surprise, in an effort to remember that the world in fact, can and will go on. ${ }^{11}$

${ }^{11}$ Shotwell, Against Purity, 203. 
Chicken Little stated, "The sky is falling!" This claim was often chalked up to hysteria, fear, and exaggeration associated with an event that would never happen. Perhaps Chicken Little was right; the sky has already fallen, and the task at hand is to create meaning from the mess. Many things are entangled and true at once, and everything we touch is touching us. 


\section{REFERENCES}

Blick, Fred. "Wordsworth, Coleridge, Science and Flashing Flowers: The Influence of Elizabeth Linnaeus and Erasmus Darwin.” https://www.academia.edu/12902335/Wordsworth_Coleridge_Science_and_Flashi ng_Flowers_The_Influence_of_Elizabeth_Linnaeus_and_Erasmus_Darwin, (March 25,

Burbridge, Ben, and Annebella Pollen, Photography Reframed: New Visions in Contemporary Photographic Culture. London and New York: I.B. Tauris Ltd. \& Co., 2018.

Frow, John. "Tourism and the Semiotics of Nostalgia." October, (57). 123-151. http://hdl.handle.net/11343/34273

Greenberg, Clement. “avant-garde and Kitsch.” Art and Culture: Critical Essays. Boston, Beacon Press, 1984, pp:3-21.

Shotwell, Alexis. Against Purity: Living Ethically in Compromised Times. Minneapolis: University of Minnesota Press, 2016.

Solnit, Rebecca. Field Guide to Getting Lost. Penguin Books, 2006

Solnit, Rebecca. Hope in the Dark: Untold Histories, Wild Possibilities. Chicago: Haymarket Books, 2016.

Solnit, Rebecca. Storming the gates of paradise: landscape for politics. Berkely and Los Angeles: University of California Press Ltd., 2007.

Steyerl Hito, “In Defense of the Poor Image.” e-flux. Journal \#10-November 2009. https://www.e-flux.com/journal/10/61362/in-defense-of-the-poor-image/

Tsing, Anna, Heather Swanson, Elaine Gan, Nils Bubandt. Arts of Living on a Damaged Planet. Minneapolis: University of Minnesota Press, 2017. 2019). 
Umbrico, Penelope. American, Philadelphia, Pennsylvania, 1957. 2009. 5,377,183 Suns from Flickr (Partial) 4/28/09. photograph. Place: San Francisco Museum of Modern Art, Members of Foto Forum purchase.

https://library.artstor.org/asset/ASFMOMAIG_10312704263 . 